\title{
The Status and Trends of China English
}

\author{
Yihua Zhang ${ }^{1} \&$ Hanfu Mi ${ }^{2}$ \\ ${ }^{1}$ Guangdong University of Foreign Studies, Guangzhou, China \\ ${ }^{2}$ University of Illinois at Springfield, Springfield, IL, USA \\ Correspondence: Hanfu Mi, University of Illinois at Springfield, One University Plaza, Springfield, IL, 62703-5407, \\ USA.
}

Received: January 8, 2020

doi:10.5430/wjel.v10n1p20

\author{
Accepted: January 29, $2020 \quad$ Online Published: February 21, 2020 \\ URL: https://doi.org/10.5430/wjel.v10n1p20
}

\begin{abstract}
The status and trends of China English, as documented and analyzed in Bolton and Graddol (2011), are recurring topics of intense research interest in many linguistic studies, especially for some bilingual collaborative scholars from both western countries and China. The current paper attempts to describe the status of China English and analyze its trends based on relevant corpus data. The exuberance and vibrancy of China English are reflected in nativized English from Chinese, Chinese loanwords in English, and the pragmatics and functional use of China English. The corpus data analyses strongly support the practice of employing various calques in treating China-specific or culture-bound words, such as phonological calque, semantic calque, phono-semantic calque, and referential calque.
\end{abstract}

Keywords: China English, China-specific words, Chinese loanwords, language contact, culture-bound words

\section{Status of China English}

During more than two centuries of language contact attributable to economic and cultural exchanges between China and the West, a great number of Chinese culture-bound words, words unique to Chinese or the Chinese ethnic culture, have inevitably emerged into the English language through various channels, media or otherwise. Chinese has progressively become the most important source of newly imported English words. According to the Global Language Monitor headquartered in Texas, which collectively documents, analyzes, and tracks trends in language usage worldwide, with a particular emphasis upon the English language, Chinese has already become the number one source language of loanwords in English, adding 5 to 20 percent annually to today's English by contributing more words that have entered English since 1994 than any other single global language source (Yu, 2013). It is occurring now even more so than ever before.

Chinese borrowings or loanwords are widely used in normative English both in the past and present, and a great number of them have been accepted as entry words in many authoritative English dictionaries. While the Chinese loanwords included in the Oxford English Dictionary (OED) and Webster's Third New International Dictionary (commonly known as Webster's Third) are a good example to support this claim, nativized English in Chinese-speaking regions is another inexorable outcome of the Chinese-English language contact. With the increase of exchanges between China and western countries, an ever-growing number of China-specific words are entering and enriching normative English, which is regarded as one of the most significant features of China English.

The changes in normative English, especially lexical changes, may reflect an openness to the Chinese language and culture. To some degree, there has been a long history of mutual exchange of, in addition to commercial transactions, ideas and language, such as that Americans get tattoos of Chinese characters on their bodies, martial arts are in the mainstream, as is Chinese (American regional Chinese cuisine) food. Language reflects this openness, and the recent rapid increase in Chinese words represents perhaps an increased openness, possibly triggered by massive European and American business/missionary contact from the late 19th century to the War of Resistance against Japan (1937-1945), and the more recent opening-up of China to the world.

The purpose of this paper, in presenting the status and trends of China English, is to describe (1) the lexical development as recorded primarily in two representative, authoritative English dictionaries since the early days of language contact; (2) the pragmatics and functional uses as highlighted in the huge number of people who are speaking or learning China English and the use of culture-bound words and the Chinese loanwords; and (3) two Published by Sciedu Press 
seemingly different, yet complementary, approaches of treating the China-specific words as documented in the data extracted from the China Related English Corpus (CREC), a collection of linguistic information used to discover linguistics, especially China English, rules and principles (Note 1).

\subsection{Nativized English from Chinese and Chinese Loanwords in English}

According to Schneider's "dynamic model of the evolution of New Englishes" (2003, pp. 243-254), a New English, a locally influenced English, China English included, goes through five stages in its development: foundation, exonormative stabilization, nativization, endonormative stabilization, and differentiation. Schneider (2010), from a developmental point of view, points out that transfer from the mother tongue is a necessary and integral feature when an exonormative variety of English is being nativized as an endonormative variety. Nativization or localization is the process of adopting some language features of its own, in this case, Chinese, such as sounds, intonation patterns, sentence structures, words, and expressions. Consequentially, any nativized new variety of English would contain some forms that deviate from normative English. China English, to some extent, follows Schneider's dynamic model, and shows signs of linguistic and cultural transformation from Chinese.

Borrowing is an essential part of the outcome of language contact (Winford, 2003; O'Shannessy, 2011, p. 79). All of the loanwords serve as a reflection of language contact between Chinese and English. Winford (2003) explored lexical borrowing in language maintenance situations and provided many examples of both English and Chinese influence on the Japanese lexicon. In China English, there is also extensive borrowings from Chinese; among them, a major part of traditional borrowings is originated from Canton English. The norm-based China English, while newly emerging, enjoys an increasing influence on international communication.

An Etymological Dictionary of the English Language (W. W. Skeat, 1888) is the first to include China-specific words as loanwords: china (陶瓷), Chinese (中国人), nankeen/nankin (本色棉布), tea (茶) and typhoon (台风), all together eight words in total. A History of Foreign Words in English (M. S. Serjeantson, 1956) includes 27 China-specific words. Since the 1960s, the number of English dictionaries that contain China-specific words has gradually increased. In addition to the etymological dictionaries containing Chinese loanwords, common language dictionaries also began to include Chinese loanwords or culture-bound words in them. Since there are so many of these dictionaries, two in particular, the Oxford English Dictionary Online and the Webster's Third New International Dictionary (1989) have been selected as primary sources to illustrate how China-specific words are presented as loanwords in English dictionaries.

As discussed in the "Origin" in the Oxford English Dictionary Online, 341 "Chinese-Tibetan" loanwords are included as main entry-words, including 257 Chinese borrowings (actually 258), among which there are 39 for language, religion, and philosophy, 22 for animals and plants, 12 for society and government organization, 46 for arts and entertainment, 46 for cooking and dishes, 23 for political economy and measurements, 13 for geography and ethnics, 12 for dynasties, 9 for social occupations, 7 for medicine, 7 for clothing, 7 for martial arts, and 15 for others. The distribution in each quinquagenary is shown in the following chart and table respectively.

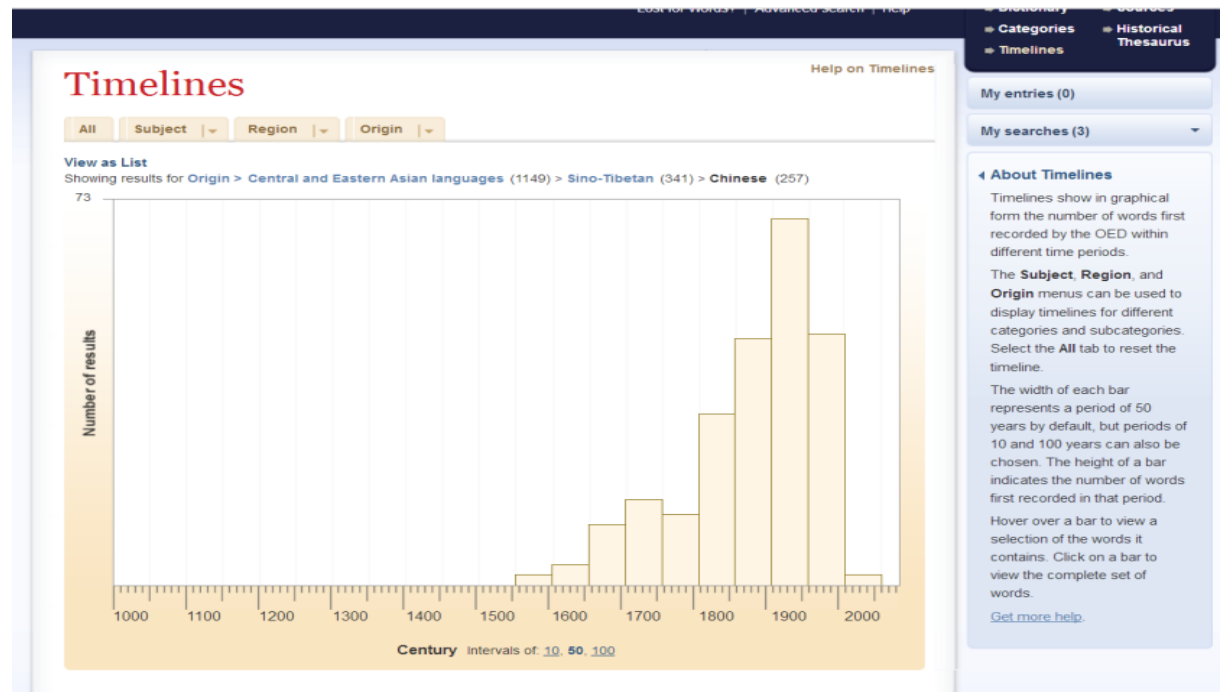

Figure 1. Chart for Semi-Centennial Distribution of Chinese Loanwords in OED

(Taken from https://www.oed.com/timelines, the Oxford English Dictionary Online) 
Table 1. Semi-Centennial Distribution of Chinese Loanwords in OED

\begin{tabular}{|c|c|c|}
\hline Quinquagenary & Quantity & Example \\
\hline $1550-1599$ & 4 & China/中国 (Note 2), china/瓷器, li/里, litchi/荔枝 \\
\hline $1600-1649$ & 4 & cha/茶, sampan/舢板, t’ien/天, tutang/督堂（governor） \\
\hline $1650-1699$ & 12 & ginseng/人参, kumquat/金橘, Shang/商 (Dynasty), yin/阴 \\
\hline $1700-1749$ & 19 & bohea/武夷茶, ketchup/番茄酱, tao/道, tai chi/太极 \\
\hline $1750-1799$ & 14 & kang/炕, pela/白蜡, pe-tsai/白菜, wampee/黄皮 \\
\hline $1800-1849$ & 34 & $\begin{array}{l}\text { bok choy/白菜, campoi/拣焙茶, kow-tow/吒头, kuan/kwan/官, moutan/牡丹, } \\
\text { senshaw/薯莨绸 }\end{array}$ \\
\hline $1850-1899$ & 49 & $\begin{array}{l}\text { ang moh/洋人, chop suey/杂碎, dizi/笛子, likin/厘金, mafoo/马夫, p’o/魄, } \\
\text { shang/埫, tai-ping/太平军 }\end{array}$ \\
\hline $1900-1949$ & 73 & $\begin{array}{l}\text { aiyah/䒝呀, baozi/包子, hutung/胡同, Latinxua/拉丁化, mien/面, subgum/素什 } \\
\text { 锦, Nanyang/南洋, yum cha/饮茶 }\end{array}$ \\
\hline $1950-1999$ & 50 & $\begin{array}{l}\text { kungfu/功夫, dai pai dong/大牌档, char siu/叉烧, char kway teow/炒粿条, } \\
\text { ganbu/干部, guanxi/关系, hongbao/红包 putonghua/普通话, wok/砂锅, } \\
\text { taikonaut/太空人 }\end{array}$ \\
\hline $2000-2015$ & 2 & goji/枸杞, boba/珍珠奶茶 \\
\hline
\end{tabular}

Most of the examples listed above, except for a few cases such as "Nanyang" and "Putonghua," are Chinese loanwords based on local pronunciation and somewhat different from the standard Pinyin of Mandarin. The reason is that the early Chinese-English language contact occurred mostly along the southeast coast, and that there was no uniform pronunciation annotation system at that time. Therefore, the translation could only be imitated in English spelling according to the local pronunciation, which was greatly influenced by "A Latin Alphabet Spelling Scheme for Chinese Characters," and then by the "Wade-Giles Romanization System." For example, "subgum, kumquat, kuan/kwan, wok, wampee, yüeh ch'in" and others have distinct Cantonese pronunciation features; while "ketchup" and "bohea" are more obviously based on the imitation of Xiamen and the northern dialects. The Chinese loanwords directly retrieved through the $O E D$ statistical tool are 257 . Actually, this number is not very accurate. The first author found two entries not accounted for by just a cursory cross-searching: Mamenchisaurus (马门溪恐龙) and Gormogon (an organization similar to the British Freemasonry). Therefore, it is certain that the Chinese loanwords included in the $O E D$ are far more than this number. The $O E D$ 's automatic statistical tool counts particularly no compound words composed of base loanwords, which are a relatively large number, for example, "China, Chinese, mandarin, china, tea, silk," and so on. Wang and Chang (2001) show that there are 65 derivative, compound, and transformational words consisting of "silk." The total number of such words, including "China," "Chinese," can reach 208. The OED Online interface retrieves 366 entries or phrases consisting of "tea;" and there are 56 compound words under the entry of "Chinese." The number is quite large if such words in explanations and references are included in the calculation.

According to Zeng and Zhang (2009), 543 entries of China-specific words are included in the Webster's New Third Edition, among which there are 101 for place names and nationality, 71 for plants, 36 for miscellany, 25 for china, 20 for clothing and literature respectively, 19 for philosophy and religion, 18 for history, 16 for business and currency, 13 for Chinese medicine and tea respectively, 12 for music and theater and antiquities and traditional culture respectively, 11 for games and calligraphy respectively, and 27 for other categories such as people, occupations, politics, measurements, festivals, martial arts, et cetera. In these entries, except for the 101 for place names and nationality, most are free translation and compound words. There are only 145 loanwords that can be directly translated by real phonetic imitation. In addition to the place names and nationality, there are altogether 246 entries. The number of Chinese loanwords included is amazingly similar, if not equivalent, to $O E D$.

It is worth mentioning that there are 21 Chinese loanwords in the Nine Thousand Words supplementary to the Webster's New Third Edition in 1983, including not only the traditional vocabulary words such as "bok choy/白菜 (Chinese cabbage: lit. white vegetable), cheongsam/旗袍 (lit. Manchurian dress, a close-fitting woman's dress with 
high neck and slit skirt, popular in China of the 19th and early 20th centuries), chiao/角, Chien ware/宋瓷, tai chi ch'üan /太极拳 (tai chi, Great Ultimate, or T'ai Chi Ch'üan, usually miswritten as Tai Chi Chuan, a form of physical discipline, lit. Great Ultimate (fist =) Fighting)" and others, but also words of modern concepts or new discoveries such as “renminbi/人民币, running dog/走狗, Lantian Man/蓝田猿人, Maoism/毛泽东主义/思想, Peking duck 北京 鸭, Pekingology/北京问题研究,” and others (See Wang, 1986).

The Webster's New International Dictionary (2nd ed., 1934, xiv) notes that, "in addition to proper names, more than a hundred words of Chinese origin have come into the English language, largely as a result of early trade contacts with China, ..." According to Cannon (1988), the number of Chinese loanwords in English had already reached 1,189 at that time. Most recently, Yihua Zhang (2018) conducted a detailed comprehensive statistical analysis by entry of several English dictionaries as evidence in China English codification. Based on his analysis, the Oxford English Dictionary Online (2018) contains 542 Chinese loanwords, some of which are included as sub-entries; whereas the Webster's New Third Edition (1961/1996), online as Webster's Third, Unabridged, comprises about 730 entries of Chinese loanwords. This means that English dictionaries at large pay attention to the inclusion of Chinese loanwords and maintain open and accepting towards China's distinctive culture.

\subsection{Pragmatics of China English}

Bolton (2003, p. 228) observed that even close to 20 years ago "there has been a dramatic and rapid spread of English throughout China in the last forty years or so." With an ever-growing number of people speaking and learning English in China, it is not surprising that China English has been emerging and developing rapidly. Rong (1991) discussed such a phenomenon and the evolution of China English. Later, several other scholars (Li, 1993; Jia \& Xiang, 1997; Du, 1998) respectively expounded the pragmatics of China English from different perspectives. On the one hand, the existence of China English as a variant of English is an indisputable fact in international communication; on the other hand, there is a huge population acting as speakers of China English. According to the Ministry of Education of China (2019), in 2018, there were 38.33 million college students, 39.67 million high school students, and 44.42 million middle school students, most of whom were learning and speaking English. It is estimated that 450 million Chinese people have learned or are learning English (Baidu Library, 2013). One of the important reasons for so many people learning English is that English enables them to express themselves in international communication or promote their businesses in an increasingly global market. It is China English that makes this international communication possible; and it will continue to play an increasingly significant role in the process of international communication.

Due to cultural differences reflected in Chinese and western languages, Chinese and foreign, especially western, media and writers adopt different approaches to dealing with China-specific words or concepts. Based on our corpus analysis (see Note 1 and Figure 2), it is clear that the Chinese media tend to use free translation, while British and American media tend to use traditional Wade Giles transcription instead of free translation. Usually, when Chinese people are struggling for clarity and precision in expressing a Chinese word in English, western media have already found its "English equivalent" through phonological calque (usu. traditional Wade Giles transcription). Therefore, in recent years Chinese hot words are often seen in the form of pinyin in western media, such as dama/大妈 (aunt), tuhao/土豪 (local tycoon), xiao huangdi/小皇帝 (little emperor), chengguan/城管 (urban management personnel), fenqing/愤青 (angry youth), and bu zheten/不折腾 (Don’t waste effort). Although there exist diverse English versions of those words, western media and writers prefer to adopt phonological calque to deal with the issues in translating China-specific words.

For instance, during the 2008 Beijing Olympic Games, the nonstop chants of "Jia You" (加油/step on the gas) gave rise to foreign journalists' high interest in this Chinese expression. However, no one could propose an accurate translation apart from cheer up, come on, bring it on, let's go, score, and so on. While all of which contain its general meaning, none of which capture its distinctive quintessence. Ultimately, most foreign media made the direct use of "jiayou" (lit. add fuel) in their coverage. Recently OED Online included a sub-entry add oil to add, expressing encouragement, incitement, or support: go on! go for it! This seems to be one of the culture-bound words that there is no precise alternative but to simply retain the original, which might be indeed one of the simplest and most effective methods. Initially, it could be necessary to add an annotation to the phonological calque to explain its implication. This is an interim operational approach to reduce and eliminate readers' confusion and enhance their understanding of China-specific words. For example, Kluger (2013) translated “小皇帝” as “xiao huangdi - or little emperor” in The Times; the two parts: phonological calque and referential calque confirm each other. Connor (2013) translated the same word “小皇帝” as “'little emperors'- the offspring of one-child families born..." on the same day in The Independent; the two parts: referential calque and 
free translation confirm each other. In like manner, the following examples all demonstrate these features:

双喜: the shuangxi (double happiness), Double happiness (Shuangxi/双喜); 八卦: Bagua (Eight

Trigrams/Diagrams), Chinese Eight Trigrams of Bagua; 国子监: Guozijian-Imperial Academy; 四书：Ssu Shu一Four Books; 大学：ta hsüeh— great learning; 风水：feng-shui-geomancy, geomantic omen; 八股文: baguwen, eight-part essay, eight-legged essay, to write in the Pavilion Style, a regius and solemn type of writing.

English writers seem more willing to use both phonological and referential calques in tandem or directly use the phonological calque by itself, implying that they expect their readers to be more accepting of bringing Chinese words into their vocabularies, in addition to the concepts that those words signify.

\section{China English As Analyzed Based on CREC Data}

Trends in China English, especially the contrastive, sometimes complementary, usage by the English native speakers versus the China English speakers, are analyzed and predicted based on relevant corpus data extracted from the China-Related English Corpus (CREC) (Note 1). The CREC is an approximately 100 million-word collection of written English texts about China, which consists of three sub-corpora. The Sub-Corpus 1 (SC-I) contains texts from native English web media and printed materials concerning China and Chinese culture; the Sub-Corpus 2 (SC-II) comprises texts collected from China domestic English web media, English books written by Chinese natives, and the translated English versions of Chinese books. The third one is a specialized corpus of the Chinese Repository (oftentimes regarded as an additional part of SC-I with a specific time period limitation), an English periodical edited by the American missionaries Bridgman (1801-1861) and Williams (1812-1884), which was published in Canton between May 1832 and 1851, reflecting the primary stage of language contact between Chinese, Cantonese more precisely, and English (see Figure 2).

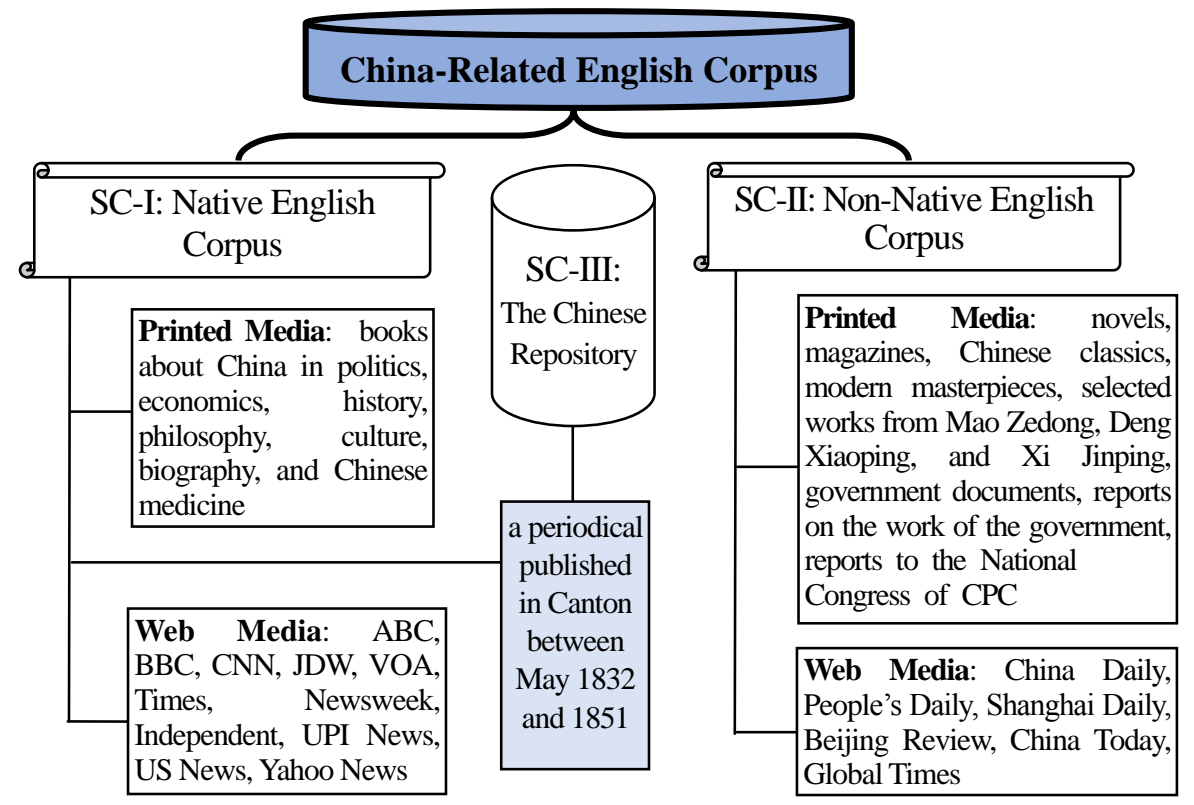

(Note 3)

Figure 2. Material Sources of the China-Related English Corpus (CREC)

All the books or texts are selected according to their relatedness to China and China's affairs through a series of selection procedures. The composition of language materials in the corpus is shown in Table 2.

Table 2. Composition of Language Materials in CREC

\begin{tabular}{cccc}
\hline Sub-Corpora & Source & Number of Tokens & Sub total \\
\hline SC-I & Printed Matter & $22,560,226$ & $47,472,526$ \\
& Web Matter & $24,912,300$ & \\
\cline { 2 - 4 } SC-II & Printed Matter & $9,829,201$ & \multirow{2}{*}{$42,218,628$} \\
\cline { 2 - 4 } & Web Matter & $32,389,427$ & $5,145,835$ \\
\hline SC-III & Printed Matter & $5,145,835$ & \multirow{2}{*}{ ISSN 1925-0703 E-ISSN 1925-0711 }
\end{tabular}




\subsection{Purposeful Use of China English Words}

As stated above, Chinese and western media and writers seem to adopt different approaches to dealing with China-specific words or concepts, and, therefore, they have different views towards the purposeful use of China English. In this study, 1,231 China-specific words are extracted from the Sub-Corpus I and II in order to facilitate the analysis of the difference in purposeful use of China-specific words by Chinese domestic and western media respectively, which offers a glimpse into the developmental tendency especially in lexicon of China English.

For this reason, a comparative analysis of words with a frequency beyond 100 is carried out. First, 176 and 215 words are extracted from Sub-Corpus I and II respectively. Following a detailed comparison, 124 words are found to be co-existing in the two sub-corpora, making up $70 \%$ of the 176 comparable words. The principal difference shows that 11 high-frequency words do not appear in Sub-Corpus I in contrast to Sub-Corpus II, and that 4 high-frequency words cannot be found in Sub-Corpus II. In order to confirm these statistics, the analysis has been expanded to include all 1,231 words, revealing the ratio of difference to be almost the same with an absence of 258 in Sub-Corpus I and 134 in Sub-Corpus II. This analysis, at least, shows that Chinese and English writers and/or translators share a large commonality in terms of China English usage, and the difference is only limited to a small number of words. The major commonality reflects the basis of cross-culture communication, serving as positive factors to promote the international exchange. However, a difference of approximately $30 \%$ remains an obstacle to effective communication. It is critically important to develop a clear understanding of the occurrence mechanism of these differences, and create a way to communicate these differences in order to promote the trade and cultural exchanges among different countries.

\subsection{Features of Language Use in Sub-Corpus I}

Among the 134 words which are absent in Sub-Corpus II, 73 of them are phonological calque (transliteration), accounting for close to $55 \%$ of the total; where only 16 words are found calqued in pinyin, accounting for $12 \%$ of the total, while $83 \%$ are in traditional Wade Giles transcription, e.g., Hoisin (海鲜/seafood), Manchu epoch (满洲时期 /Manchurian period), Ch'ing (清/Qing Dynasty), Yenan (延安/Yan'an ), t’ien (天/heaven), fu yung (芙蓉蛋/omelet), Ch'ien Lung (乾隆帝/Emperor Qianlong), Kuan Yin (观音/Avalokitesvara), Ch'an (禅宗/Zen), and Quemoy Matsu (金门妈祖/Quemoy Mazu).

The preferred approach by the western media is by far the referential calque. This is mostly limited to stereotypical words, which can be interpreted according to individual constituents, such as "yellow jacket (黄马补), Great Northern Wilderness (北大荒), stinking ninth category (臭老九), responsibility contract (包干合同), and old hundred names (老百姓).” This category of words is rarely seen in China media, especially rigid word for word translations like "old hundred names." In addition, some expressions with a frequency from 10 to 40 in Sub-Corpus I, such as Propaganda Bureau (宣传部), Dragon chip (龙芯), Spark Program (星火计划), West East gas pipeline (西气 东输), are not found in China English media. Because contemporary scholars have recognized that the image and implication of dragon and propaganda are not the same as those of “龙” and “宣传” in their indigenous and traditional sense, which may present a negative implication. China English speakers, especially people from the Chinese mainland, try to avoid using these words in the above phrases. As for “龙芯," a special spelling like "Loongson" is frequently used in China media.

\subsection{Features of Language Use in Sub-Corpus II}

Among the 258 words which are absent in Sub-Corpus I, 159 of them are referential calque, accounting for $62 \%$ of the total, e.g., home purchase restrictions (住房限购), affordable housing projects (安居工程), Torch Program (火炬 计划), gaokao reform (高考改革), and door god (门神). Among 99 phonological calques, 90 words are transliterated in Chinese pinyin, accounting for $91 \%$ of all the transliteration, which stands in sharp contrast to the situation of Wade Giles transcription in Sub-Corpus I; for example, Xuan paper (宣纸/rice paper), aoshu (奥数), gaotie (高铁 /high-speed rail), Bei Shang Guang (北上广/Beijing, Shanghai, Guangzhou), and gao da shang (高大上). Some of them are phono-semantic calques: Wing Loong (翼龙战机/pterosaur fighter), chengguan officer (城管), and Qixi Festival (七夕).

The preferred approach by the Chinese media is the free translation, when the translation is rendered closer or caters more to British and American readers and their reading habits, which might explain the absence in utilizing phonological or referential calques. For example, “二胡” and “八卦” are often translated as Chinese violin and Eight Diagrams or Eight Trigrams, although the corresponding phonological calques erhu and pa-kua had already been 
included in $O E D$. The same is true for Chinese idioms or idiomatic expressions, “破釜沉舟” being translated as to cut off all means of retreat or to burn one's own way of retreat, and “鱼米之乡/land of fish and rice” being simply replaced by an English idiom land of milk and honey.

\section{Discussion}

China's domestic media tend to adopt a domestication approach to translation in dealing with China-specific words by means of free translation; that is more or less due to the influence of the traditional culture, and for fear that English natives do not understand phonological calques or strict literal translation. Much attention has been paid to interpreting semantic aspects of the words, ignoring the fact that equivalents are frequently unavailable in the English language. Thus, a great number of Chinese culture-bound words and idioms have been turned into English by free translation, which oftentimes do not fully reflect the original and authentic meanings of the source idioms. For example, Milk and honey in the above translation land of milk and honey is a comparison derived from the Bible, while the source idiom is a realistic depiction of a picturesque rural scenery with rich resources, in the south of the lower reaches of the Yangzi River of China. Consequently, it would be better to translate “鱼米之乡” as land of fish and rice; and for the same reason, “破釜沉舟” as to break the caldrons and sink the boats. If the translator or writer thinks that such translation may cause difficulty in comprehension for English native speakers, an annotation such as to cut off all means of retreat could be added to the idiom for the latter example.

British and American media, used to the Wade Giles transcription and the Chinese loanwords included in English dictionaries and accustomed to addressing themselves to Chinese traditional stories and events, tend to adopt a foreignizing approach to translation by means of phonological calque through Wade Giles transcription. However, they are not adapted to China-specific words based on pinyin which can be frequently seen in Chinese English media. In addition, little attention has been paid to newly-emerged concepts in contemporary China, and few new China-specific words can be found in Sub-Corpus I. From the statistics extracted from the Corpus, there are 11 high-frequency words which are absent in the native English Corpus, such as festival travel rush (节日旅游高峰), Shanghai FTZ (上海自贸区), Minguo Period (民国时期), mortgage slave (房奴), tax for fee (费改税), and Hanfu (汉服), which are words regarded as hot topics in China in recent years. This indicates that western media have not paid enough attention to the latest development or major events currently taking place in China.

From the above discussion, it is found that China English is loaded with China-specific and culture-bound words. Some specific words or expressions have no equivalents in English, which remains a linguistic and cultural barrier difficult to overcome. In this case, free translation may only communicate part of the meaning, and lose the essential indigenous features of the source; literal translation may become more or less unintelligible or confusing to English native speakers. This is presumably why western media have to adopt phonological calque (transliteration) to communicate, especially when the Chinese cultural connotations are abundant. This translation approach started when Marrison's Latin Alphabet Spelling started 190 years ago, because such a phonetic system is based on 26 letters as phonetic symbols, close to the English spelling. China's media should take into account China English pragmatics, strategies of communication, and make a concerted effort to employ various calques in treating China-specific words, such as phonological calque, semantic calque, phono-semantic calque, and referential calque. By using phonological calque, for example, instead of free or literal translation, English writers expect their readers to get to know Chinese culture and language and to bring aspects of Chinese language into their vocabularies and mental constructs.

\section{References}

Baidu Library. (2013). The Status Quo of Chinese Learning English. Retrieved from https://wenku.baidu.com/view/65c72be64028915f814dc227.html

Bolton, K. (2003) Chinese Englishes: A Sociolinguistic History. Cambridge University Press.

Bolton, K., \& Graddol, D. (2012). English in China today. English Today, 28(3), 111. https://doi.org/10.1017/S026607841200034X

Cannon, G. (1988). Chinese borrowings in English. American Speech, 63(1), 3-33. https://doi.org/10.2307/455420

Connor, S. (2013, January 10). One-child policy: China's army of little emperors. The Independent.

Du, Z. (1998). World English context and language and culture in China English. Foreign Language and Foreign Language Teaching, 8, 14-16.

Huang, H. (1992). On the etymology of China and others. Modern Foreign Languages, 2, 36-40.

Jia, G., \& Xiang, M. (1997). A Defense for China English. Foreign Language and Foreign Language Teaching, 5, Published by Sciedu Press 
10-11.

Kluger, J. (2013, January 10). China's one-child policy: Curse of the "little emperors". The Times.

Li, W. (1993). China English and Chinese English. Foreign Language Teaching and Research, 4, 18-24+80.

Liu, Z. (2000). Etymological research on China and Cathay. Fujian Foreign Languages, 3, 6-12.

Ministry of Education of China. (2019). China Education Profile: Development of Education in the Country in 2018. Retrieved from http://www.moe.gov.cn/jyb_sjzl/s5990/201909/t20190929_401639.html

Online Etymology Dictionary. Retrieved from https://www.etymonline.com/

O'Shannessy, C. (2011). Language contact and change in endangered languages. In P. K. Austin, \& J. Sallabank (Eds), The Cambridge Handbook of Endangered Languages (pp. 78-99). Cambridge: Cambridge University Press. https://doi.org/10.1017/CBO9780511975981.005

Oxford English Dictionary. (1928/1989). Oxford University Press.

Oxford English Dictionary Online. Retrieved from https://www.oed.com/ Oxford University Press.

Rong, P. (1991). China English is an objective existence. Journal of PLA University of Foreign Languages, 2, $1-8+56$.

Schneider, E. W. (2003). The dynamics of new Englishes: From identity construction to dialect birth. Language, 79(2), 233-281. https://doi.org/10.1353/lan.2003.0136

Schneider, E. W. (2010). Developmental patterns of English: Similar or different? In A. Kirkpatrick (Ed.), The Routledge Handbook of World Englishes (pp. 372-384). London: Routledge.

Serjeantson, M. S. (1956). A History of Foreign Words in English. New York: E. P. Dutton and Company.

Skeat, W. W. (1888). An Etymological Dictionary of the English Language. Oxford: Clarendon Press.

Wang, R. (1986). Chinese loanwords in the English language. Foreign Languages and Their Teaching, 1, 8-14.

Wang, R., \& Chang, J. (2001). Sources of Chinese borrowings in English. Journal of Sichuan International Studies University, 4, 70-73.

Webster's New International Dictionary of the English Language (2 ${ }^{\text {nd }}$ ed.). (1934). Merriam-Webster Inc.

Webster's Third New International Dictionary of the English Language (1961/1996). Merriam-Webster Inc.

Winford, D. (2003). Introduction to Contact Linguistics. Oxford: Blackwell Publishing.

$\mathrm{Wu}, \mathrm{T}$. (1988). Chin's contributions to the world viewed from the foreign language vocabulary. Shandong Foreign Language Teaching, l, 1-14.

Yu, G. (2013, December 2). The Chinese words that we have "exported" in recent years. People's Daily (Overseas Edition).

Zeng, T., \& Zhang, Z. (2009). On the direction of English translation of Chinese cultural-bound words: A case study of Chinese loanwords in Webster's Third New International Dictionary of the English Language. Lexicographical Studies, 5, 34-50.

Zhang, Y. (2018). A study on a China-related English language knowledge base and the construction of its application systems. A Research Report for a Key Programme of National Social Science Grant. Guangdong University of Foreign Studies.

\section{Notes}

Note 1. The China-Related English Corpus (CREC) is hosted and maintained at the first author's university, the Guangdong University of Foreign Studies in Guangzhou, China.

Note 2. The origin of the name, China, is still regarded as a matter of debate in OED as a possible outcome from China's Qin dynasty. However, it has been documented that the name is indeed originated from the sound of Chin several hundred years B.C. (Wu, 1988; Huang, 1992; Liu, 2000).

Note 3. CREC SC-I web media include:

$\mathrm{ABC}$ - Australian Broadcasting Corporation 
BBC - British Broadcasting Corporation

CNN - Cable News Network

JDW - Jane's Defence Weekly

VOA - Voice of America

Times - The Times Weekly

Newsweek - An American weekly news magazine

Independent -- The Independent Media Center (also known as Indymedia or IMC)

UPI News - United Press International

US News - U.S. News \& World Report

Yahoo News - Yahoo! News 